\title{
Toxicity Mechanism of Emodin on Interstitial Cells of Cajal
}

\author{
Cheng Peng ${ }^{1,2,3 *}$, Yanhong Wang ${ }^{4}$, Yunxia $\mathrm{Li}^{1,2,3}$ \\ ${ }^{1}$ Pharmacy College, Chengdu University of Traditional Chinese Medicine, Chengdu, China; ${ }^{2}$ The Ministry of Education Key Labo- \\ ratory of Standardization of Chinese Herbal Medicine, Chengdu, China; ${ }^{3}$ State Key Laboratory Breeding Base of Systematic Re- \\ search, Development and Utilization of Chinese Medicine Resources, Chengdu, China; ${ }^{4}$ Department of Pharmacy, Second Affiliated \\ Hospital (Binjiang Branch), Zhejiang University School of Medicine, Hangzhou, China. \\ Email: " pengchengsub@126.com
}

Received March $4^{\text {th }}, 2013$; revised April 26 ${ }^{\text {th }}, 2013$; accepted May $13^{\text {th }}, 2013$

Copyright (C) 2013 Cheng Peng et al. This is an open access article distributed under the Creative Commons Attribution License, which permits unrestricted use, distribution, and reproduction in any medium, provided the original work is properly cited.

\begin{abstract}
Aim: To explore the emodin's toxicity and action mechanism on the function of interstitial cells of Cajal (ICC) cultured in vitro. Methods: ICC of KM mouse was cultured in vitro. The minimum toxicity concentration and critical time points of emodin were investigated with Uniform Design methodology and MTT assay. The cell enzymology assay and enzyme immunoassay (EIA) were applied to observe the effect of emodin on membrane stability, cellular internal environment, energy metabolism and second messenger of ICC. Results: The minimum toxicity concentration was $0.001 \%$, and the critical time points were $30 \mathrm{~s}, 1 \mathrm{~min}, 30 \mathrm{~min}$, and $60 \mathrm{~min}$. After administration of emodin, the damage on cells aggravated with time prolonging. The activity of malonaldehyde (MDA), lactate dehydrogenase (LDH), and phosphatase in the cell was raised significantly $(\mathrm{P}<0.01)$. The concentrations of $\mathrm{Na}^{+}$and $\mathrm{Ca}^{2+}$ were increased but $\mathrm{K}^{+}$concentration was decreased. The $\mathrm{Na}^{+}-\mathrm{K}^{+}$-ATPase activity was promoted but $\mathrm{Ca}^{2+}$-ATPase descended. Second messenger as IP3 and cAMP also became more active. All these changes had statistical significance $(\mathrm{P}<0.01)$. Conclusion: Emodin had toxicity function on ICC which can lead to membrane damage, energy metabolism disorder. This mechanism could be related to electrolytes concentration disorder, inhibited activity of $\mathrm{Na}^{+}-\mathrm{K}^{+}$-ATPase and $\mathrm{Ca}^{2+}$-ATPase, and raised activity of IP3 and cAMP.
\end{abstract}

Keywords: Emodin; ICC; Toxicity; Mechanism

\section{Introduction}

Chronic constipation is a common and costly complaint. More than 4 million patients per year complain of frequent constipation [1]. The interstital cells of Cajal (ICC), known to generate the slow wave activity and to be involved in intestinal neurotransmission and the enteric nervous system (ENS), are suspected to play an important role in normal intestinal motility. Their role as intestinal pacemakers has been reported in many studies. ICC in vitro produce electrical slow wave and are the source of smooth muscle rhythmic electrical activity in the normal intestine [2-4]. Electrical slow wave are not observed in mice lacking ICC networks which demonstrate the absent or delayed intestinal motility $[5,6]$. ICC are also found to be diminished or lost in human disease with associated alterations in gastric and small intestinal

${ }^{*}$ Corresponding author. motility, such as diabetic gastroparesis [7], intestinal pseudo-obstruction $[8,9]$, and congenital absence of the enteric nervous system etc. [10]

Rhubarb (Da Huang) is one of the oldest and bestknown Chinese herbal medicines, first recorded in the Classic of the Materia Medica [11], Shen Nong Ben Cao Jing of the Han dynasty, and is classified as a top medicinal plant [12]. As described in Pharmacopoeia of People's Republic of China, the most commonly used species are Rheum palmatum L., Rheum tanguticum' Maxim. Ex Balf. Or Rheum officinale Baill., and are widely used in clinic to relieve constipation by purgation [13]. However, long term administration of rhubarb will cause slow transit constipation (STC) and secondary constipation after discontinuation. It was reported that long term use of rhubarb could have impairment on ICC which probably was the important reason for gastro-intestinal disorder [14-16]. 
Emodin (Figure 1) is the main active ingredient of rhubarb $(2.6 \%)$, and is also used in the treatment of constipation. In the early investigation, our lab found that emodin could antagonize the toxic effect of aconitine on colonic ICC [17]. But in the same time, we also found emodin had toxicity effect on colon ICC. The results showed that emodin had efficacy or toxicity on ICC according to different dosage. In the study, we further investigate the toxicity mechanism of emodin on ICC function to explain the toxicity of rhubarb, uncover the substantial base of digestion disorder caused by rhubarb, and provide the reference for clinical safety dosage.

\section{Materials and Methods}

\subsection{Drugs and Animals}

Emodin was obtained from the National Institute for the Control of Pharmaceutical and Biological Products (Beijing, China). PBS (Lanzhou National Hyclone Bio-Engineering Co., Ltd., China); M199-culture medium, Collagenase type II, Ficoll 400 and MTT (Sigma Co., Ltd., USA); acetone (Cheng du Kelong solution Co., Ltd.), goat serum (Zhongshan Goldenbridge Biotechnology Co., Ltd), c-kit mAb (Wuhan Boster Biological Technology, Ltd.), anti-Rabbit IgG (Beijing Biosynthesis Biotechnology Co., Ltd.), all kits (Nanjing Jiancheng Bioengineering Research Institute).

The KM neonate mice (10 - 15 days old) were supplied by the Animal Experiment Center of Chengdu University of Traditional Chinese Medicine. All animal studies were performed according to the Guidelines for the Care and Use of Laboratory Animals that was approved by the Committee of Ethics of Animal Experimentation of Chengdu University of Traditional Chinese Medicine.

Emodin powder was weighted precisely and dissolved with $1 \mathrm{~mol} / \mathrm{L} \mathrm{NaOH} \mathrm{(pH} \mathrm{was} \mathrm{adjusted} \mathrm{to} 7.0$ using M199). The emodin solutions were prepared before experiment.

\subsection{Cell Isolation and Identification}

The isolation of colon ICC cell was established in our laboratory [17] with some modifications of the former

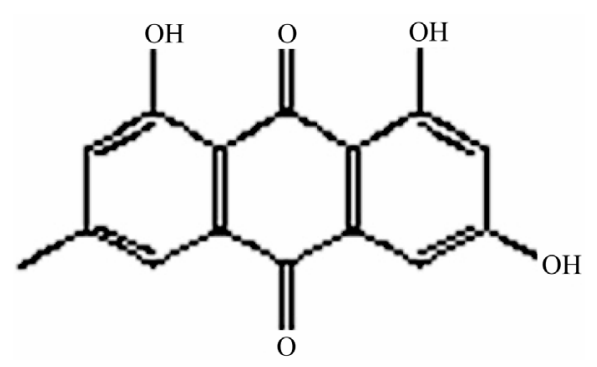

Figure 1. The chemical structure of emodin. reports $[18,19]$. Colons of KM mices $(10-15$ d) were isolated and washed twice with ice-cold PBS solution. After removal of serosa, mucosa and blood vessels, colons were digested in PBS containing $1.3 \mathrm{mg} / \mathrm{mL}$ collagenase type II at $37^{\circ} \mathrm{C}$ for $10 \mathrm{~min}$, and the cell suspension was collected. This process was repeated three times. Then cell suspensions were centrifuged at $4^{\circ} \mathrm{C}$ and 1500 rpm for $3 \mathrm{~min}$, and the pellet was resuspended in $10 \mathrm{~mL}$ Medium 199, and filtrated. $5 \mathrm{~mL}$ cells filtrate were added into centrifugal tube with $5 \mathrm{~mL}$ Ficoll 400 , and then were centrifuged at $500 \mathrm{rpm}$ for $10 \mathrm{~min}$. The cells sediments in the middle of two fluid levels were collected and diluted to $1 \times 10^{5}$ cell $/ \mathrm{mL}$ with Medium 199 (supplemented with $20 \% \mathrm{NBS}, 50 \mu \mathrm{l} / \mathrm{mL}$ antibiotic-antimycotic solution and $10 \mathrm{ng} / \mathrm{mL}$ recombinant Murine SCF). Cells were plated on 24-well culture plates and maintained at $37^{\circ} \mathrm{C}$, in $5 \%$ $\mathrm{CO}_{2}$ incubator. After $24 \mathrm{~h}$, a confluent monolayer of slowly synchronously ICC cell was developed. The medium was replenished every $2-3$ d. Figures 2(a)-(c) showed the cell morphology of ICC in logarithmic growth phase.

ICC cells were identified after being cultured for 12 days. Cells were washed 3 times with PBS solution, and then fixed with acetone (1:1 dilution with PBS.) for 10 min. After cells were blocked with goat serum for $30 \mathrm{~min}$, c-kit $\mathrm{mAb}\left(1: 100\right.$ dilution) were added at $4{ }^{\circ} \mathrm{C}$ to stay overnight. FITC-labeled Anti-Rabbit IgG (1:50 dilution) was added to stay $1 \mathrm{~h}$ in dark at normal temperature. Finally the cells were washed three times with PBS solution, and observed under fluorescence microscope (Leica) after $150 \mu \mathrm{l}$ PBS was added to each hole (Figure 3).

\subsection{Measurement of Minimum Toxicity Concentration and Critical Time of Emodin on Colonic ICC}

To investigate the minimum toxicity concentration of emodin on the function of colonic ICC, uniform design was used to design the study. Two factors (concentration and action time) and 7 levels for each factor were set up based on uniform design table $\mathrm{U}_{7}\left(7^{4}\right)$. After the cells were equilibrated with M199 for 24 h, emodin of different concentrations were added and remained for the scheduled time respectively. Cell viability as an index of drug toxicity was measured by MTT assay. Water-soluble MTT entered the cells by passive and/or active mechanisms, and subsequently it was reduced to its waterinsoluble formazan product by flavin oxidase [20]. In brief, following the partial removal of culture medium, cells were incubated with MTT $(5 \mathrm{mg} / \mathrm{mL})$ for $4 \mathrm{~h}$ at $37^{\circ} \mathrm{C}$. Then the medium was removed, and cells were oscillated in $150 \mu \mathrm{l}$ DMSO for 15 min using the decolorization shaker. Finally, the optical density (OD, Table 1) was measured at $490 \mathrm{~nm}$ using the automatic enzymelinked immunosorbent assay systems (Thermo Co., Ltd.). 


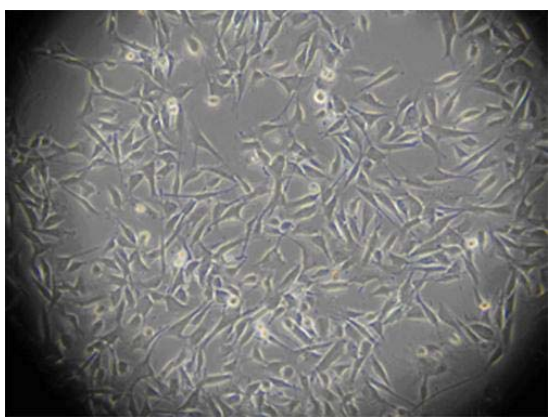

(a)

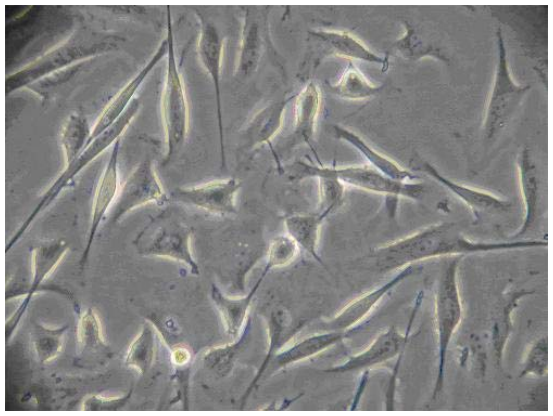

(b)

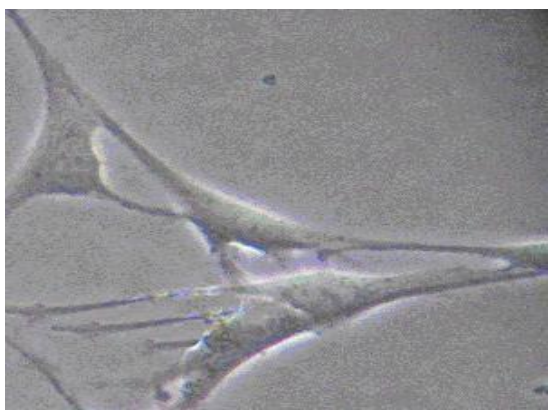

(c)

Figure 2. (a) The $12^{\text {nd }}$ day of ICC $(\times 100)$ The irregular shaped cells connected together via ecphyma, the formation of network structure; (b) The $10^{\text {th }}$ day of ICC $(\times 200)$ ICC are spindle-shaped, triangular. They connected neighboring cells via ecphyma; (c) The $12^{\text {nd }}$ day of ICC $(\times 400)$ ICC have the large nuclear and a small amount of perinuclear cytoplasm.

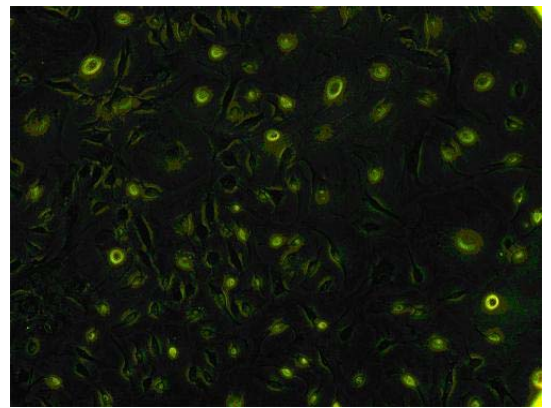

Figure 3. Identification of ICC $(\times 100)$ the c-kit of ICC's surface was positive. Both the cell bodies and ecphyma showed specific green. Cells linked up with each other, showing a large amount of ICC cells.
Table 1. OD value of emodin in $490 \mathrm{~nm}$ with different concentration and time ( $\bar{X} \pm \mathrm{SD}, \mathrm{n}=8)$.

\begin{tabular}{cccc}
\hline group & C & Time $(\mathrm{min})$ & OD value \\
\hline control & - & - & $0.2131 \pm 0.0103$ \\
1 & $1 \%$ & 360 & $0.0808 \pm 0.0013^{\mathrm{b}}$ \\
2 & $0.50 \%$ & 10 & $0.0956 \pm 0.0114^{\mathrm{b}}$ \\
3 & $0.10 \%$ & 60 & $0.1239 \pm 0.0015^{\mathrm{b}}$ \\
4 & $0.05 \%$ & 240 & $0.1163 \pm 0.0031^{\mathrm{b}}$ \\
5 & $0.01 \%$ & 0.5 & $0.1365 \pm 0.0136^{\mathrm{b}}$ \\
6 & $0.01 \%$ & 30 & $0.1208 \pm 0.0028^{\mathrm{b}}$ \\
7 & $0.00 \%$ & 120 & $0.1280 \pm 0.0016^{\mathrm{b}}$ \\
\hline
\end{tabular}

${ }^{\mathrm{a}} \mathrm{P}<0.05,{ }^{\mathrm{b}} \mathrm{P}<0.01$, vs control group.

To authenticate the minimum toxicity concentration of emodin, a serial of concentrations were set up $(0.005 \%$, $0.001 \%, 0.0008 \%$ and $0.0005 \%$ ). After equilibrating the cells with M199 for 24 h, emodin of different concentrations were respectively added and remained for $30 \mathrm{~s}$. The OD measurement was carried out as described above (Table 2).

To investigate the critical time of emodin of minimum toxicity concentration on function of ICC, emodin solution $(0.001 \%)$ were added to each well and reaction time were set as $0.5 \mathrm{~min}, 1 \mathrm{~min}, 15 \mathrm{~min}, 30 \mathrm{~min}, 60 \mathrm{~min}, 120$ $\mathrm{min}$, and $240 \mathrm{~min}$. (control group were added $200 \mu \mathrm{l}$ M199 without serum). The OD measurement was carried out as described above (Table 3).

\subsection{Toxic Effect of Emodin on Membrane, Electrolytes, ATPs, Metabolism and Second Messenger}

Drug administration: On the $12^{\text {th }}$ day, after the cells were equilibrated with M199 (without NBS, SCF and antibiotic-antimycotic solution) for $24 \mathrm{~h}, 0.001 \%$ emodin were added to each well (control group were added $200 \mu \mathrm{l}$ M199 without serum) and reaction time were set as $0.5,1$, 30 and 60 min respectively. After emodin was removed, the cells were treated as following.

To measure the concentration of MDA and LDH, M199 (containing 20\% NBS) was added to each well. And the cells were cultivated in the $\mathrm{CO}_{2}$ incubator for an hour. 200 or $500 \mu \mathrm{l}$ supernatant of each well was taken to measure the MDA or LDH concentration with MDA or LDH kit.

To measure the concentration of protein, ACP, $\mathrm{Na}^{+}$, $\mathrm{Ca}^{2+}, \mathrm{Na}^{+}-\mathrm{K}^{+}$-ATPase and $\mathrm{Ca}^{2+}$-ATPase, the cells were digested for $5 \mathrm{~min}$ with $100 \mu \mathrm{l}$ collagenase II, and then $200 \mu \mathrm{l}$ PBS were added. Cell suspension was collected to be centrifuged at $1000 \mathrm{rpm}$ for $10 \mathrm{~min}$. And then, the cell was washed and resuspended twice with PBS and the supernatant was abandoned. Deionized water was added 
Table 2. OD value of emodin in $490 \mathrm{~nm}$ with different concentration and time ( $\bar{X} \pm \mathrm{SD}, \mathbf{n}=8)$.

\begin{tabular}{cccc}
\hline group & $\mathrm{C}$ & Time (min) & OD value \\
\hline control & - & - & $0.1018 \pm 0.0042$ \\
1 & $0.0005 \%$ & 0.5 & $0.1011 \pm 0.0021$ \\
2 & $0.0008 \%$ & 0.5 & $0.1001 \pm 0.0461$ \\
3 & $0.0010 \%$ & 0.5 & $0.0883 \pm 0.0014^{\mathrm{b}}$ \\
4 & $0.0050 \%$ & 0.5 & $0.0850 \pm 0.0013^{\mathrm{b}}$ \\
\hline
\end{tabular}

${ }^{\mathrm{a}} \mathrm{P}<0.05,{ }^{\mathrm{b}} \mathrm{P}<0.01$, vs control group, all below were the same.

Table 3. Effect on OD value of $0.001 \%$ emodin in $490 \mathrm{~nm}$ $(\bar{X} \pm \mathrm{SD}, \mathbf{n}=\mathbf{8})$.

\begin{tabular}{ccc}
\hline group & $\mathrm{T}(\min )$ & OD value \\
\hline control & 240 & $0.2101 \pm 0.0044$ \\
1 & 0.5 & $0.1020 \pm 0.0014^{\mathrm{a}}$ \\
2 & 1 & $0.0939 \pm 0.0015^{\mathrm{a}, \mathrm{c}}$ \\
3 & 15 & $0.0907 \pm 0.0004^{\mathrm{a}}$ \\
4 & 30 & $0.0859 \pm 0.0016^{\mathrm{a}, \mathrm{e}}$ \\
5 & 60 & $0.0859 \pm 0.0016^{\mathrm{a}, \mathrm{e}}$ \\
6 & 120 & $0.0730 \pm 0.0013^{\mathrm{a}}$ \\
7 & 240 & $0.0715 \pm 0.0007^{\mathrm{a}}$ \\
\hline
\end{tabular}

${ }^{\mathrm{a}} \mathrm{P}<0.05,{ }^{\mathrm{b}} \mathrm{P}<0.01$, vs control group; ${ }^{\mathrm{C}} \mathrm{P}<0.05,{ }^{\mathrm{d}} \mathrm{P}<0.01$, vs group 1 ; ${ }^{\mathrm{e}} \mathrm{P}<$ $0.05,{ }^{\mathrm{f}} \mathrm{P}<0.01$, vs group 2 ; ${ }^{\mathrm{g}} \mathrm{P}<0.05,{ }^{\mathrm{h}} \mathrm{P}<0.01$ vs group 4 ; all below were the same.

to make suspension well-distributed and cells were smashed by homogenizer. Protein concentration was measured by Coomassie brilliant blue (CBB) kit and ACP concentration was measured with ACP kit. $\mathrm{K}^{+}$concentration was measured with $\mathrm{K}^{+}$kit by the method of protein hydrolysis enzyme. $\mathrm{Na}^{+}$concentration with $\mathrm{Na}^{+}$ kit were measured by turbidimetry. $\mathrm{Ca}^{2+}$ concentration with $\mathrm{Ca}^{2+}$ kit were measured by colorimetry. $\mathrm{Na}^{+}-\mathrm{K}^{+}$ATPase and $\mathrm{Ca}^{2+}$-ATPase concentration were measured with ATP kit.

The ICC metabolism was observed in the same way as the electrolyte, and glycogen concentration was measured with glycogen kit.

To measure the concentration of IP3 and cAMP, the cells were digested for 5 min after $100 \mu$ collagenase II was added, and then $200 \mu \mathrm{l}$ PBS was added. After cells were dropped off, cell suspension was collected to be centrifuged at $1500 \mathrm{rpm}$ for $5 \mathrm{~min}$. The density of the cell was adjusted to $10^{6} / \mathrm{mL}$ after being resuspended in PBS. Cells were broken and components inside them were released through repeated freezing and thawing. Then the suspension was centrifuged at $3000 \mathrm{rpm}$ for $20 \mathrm{~min}$ and the supernatant was collected to measure the IP3 and cAMP concentration with IP3 and cAMP kits.

\subsection{Statistical Analysis}

After the text edit has been completed, the paper is ready for the template. Duplicate the template file by using the Save as command, and use the naming convention prescribed by your journal for the name of your paper. In this newly created file, highlight all of the contents and import your prepared text file. You are now ready to style your paper.

\section{Results}

\subsection{Cells Isolation and Indentification}

New cultured cells were granule or clump, and most of them adhered to walls within $36 \mathrm{~h}$. The cells were variable in shape (fusiform, triangular and stellate) from the second day of adherence. The division growth speeded up, and became confertim ellipse or stellate cell which was single layer or multi layers at the $12^{\text {nd }}$ day. The irregular shaped cells connected together via ecphyma (Figure 2). These cells, labeled with an antibody to c-kit protein, formed a dense wet, showed specific green under Leica automatic microscope (Figure 3).

\subsection{Minimum Toxicity Concentration and Critical time of Emodin on Colonic ICC}

Table 1 showed the OD value after the cell was treated with emodin of different concentrations at different time. And the data were analyzed by uniform design software 3.0 (China). The equation for emodin analyzed by uniform design software 3.0 was: $\mathrm{y}=0.132-0.0716 \mathrm{X}_{1}-$ $0.0000523 \mathrm{X}_{2}+0.00011 \mathrm{X}_{1} \mathrm{X}_{2}\left(\mathrm{X}_{1}\right.$ - concentration of emodin, $\mathrm{X}_{2}$-reaction time). The result was significant: $\alpha=$ $0.05, \mathrm{~S}=6.41 \mathrm{e}-3, \mathrm{SS}=4.11 \mathrm{e}-5, \mathrm{Ft}=17.555, \mathrm{R}=$ 0.9727 . And the results showed that the minimum toxicity concentration of emodin was $0.001 \%$, and the critical time of toxic effect was $30 \mathrm{~s}$ after administration. No significant difference was found between the control group and the group treated with emodin of concentration below $0.001 \%$ (Table 2). The result verified the conclusion that $0.001 \%$ was the minimum toxicity concentration of emodin on colonic ICC.

Table 3 showed the OD value after $0.001 \%$ emodin acted on ICC for different time. Significant can be found between all treated group and control group. The OD value was continuing decreased which illustrated the toxicity. And significant can also be found between treated group $0.5 \mathrm{~min}$ and $1 \mathrm{~min}$, between treated group 1 min and $30 \mathrm{~min}$, and between treated group $30 \mathrm{~min}$ and $60 \mathrm{~min}$. Impairment of $0.001 \%$ emodin on cell was slightly increased until significant difference was found after 60 min when the toxicity already achieved a stable level and no obvious increase was observed after $60 \mathrm{~min}$. So the critical time points of $0.001 \%$ emodin on ICC 
were $0.5 \mathrm{~min}, 1 \mathrm{~min}, 30 \mathrm{~min}, 60 \mathrm{~min}$.

\subsection{Figures and Tables Toxic Effect of Emodin on ICC Membrane, Electrolytes, Their ATPase, ICC Metabolism and Second Messenger}

After colonic ICC was exposed to $0.001 \%$ emodin for 0.5 , 1, 30 and 60 min respectively, the extracelluar concentrations of MDA, LDH and ACP were increased with time. MDA concentration was increased significantly at $1 \mathrm{~min}$ after action and achieved the highest level at $60 \mathrm{~min}$. Concentrations of LDH and ACP rose remarkably since $30 \mathrm{~s}$ and rose to highest at $60 \mathrm{~min}$ as well (Table 4).

The toxic effect of $0.001 \%$ emodin on ICC was also observed under Leica automatic microscopic instrument. Ecphyma became shorten and cells slowly disconnected at $15 \mathrm{~min}$, and a significant reduction in cell number was observed (Figure 4). After $60 \mathrm{~min}$, the cell body became larger, the gap between the cell was increased which indicated the extent of cell damage became severer with time (Figure 5). $180 \mathrm{~min}$ after administration, the cell body became swell, cellular refraction disappeared, and the cell body disintegrated (Figure 6). No cell but debris can be observed at $360 \mathrm{~min}$ (Figure 7).

Table 4. Effect on MDA, LDH, ACP content in ICC of $0.001 \%$ emodin ( $\bar{X} \pm \mathrm{SD}, \mathrm{n}=\mathbf{8})$.

\begin{tabular}{ccccc}
\hline group & T (min) & MDA $(\mathrm{nmol} / \mathrm{ml})$ & LDH $(\mathrm{U} / \mathrm{L})$ & ACP $(\mathrm{U} /$ gprot $)$ \\
\hline control & 60 & $0.1007 \pm 0.0224$ & $30.1987 \pm 3.4393$ & $0.6425 \pm 0.0084$ \\
& & & $365.1937 \pm$ & \\
1 & 0.5 & $0.2306 \pm 0.0328$ & $12.5110^{\mathrm{b}}$ & $1.7191 \pm 0.0067^{\mathrm{b}}$ \\
& & & $547.5729 \pm$ & \\
2 & 1 & $0.3374 \pm 0.0255^{\mathrm{b}}$ & $32.2541^{\mathrm{b}}$ & $1.7257 \pm 0.0086^{\mathrm{b}}$ \\
& & & $730.3874 \pm$ & \\
3 & 30 & $0.3968 \pm 0.0764^{\mathrm{b}}$ & $25.0221^{\mathrm{b}}$ & $2.0810 \pm 0.0447^{\mathrm{b}}$ \\
& & & $1248.672 \pm$ & \\
4 & 60 & $0.5401 \pm 0.0435^{\mathrm{b}}$ & $37.6880^{\mathrm{b}}$ & $2.7787 \pm 0.0117^{\mathrm{b}}$ \\
\hline
\end{tabular}

${ }^{\mathrm{a}} \mathrm{P}<0.05,{ }^{\mathrm{b}} \mathrm{P}<0.01$, vs control group, all below were the same.

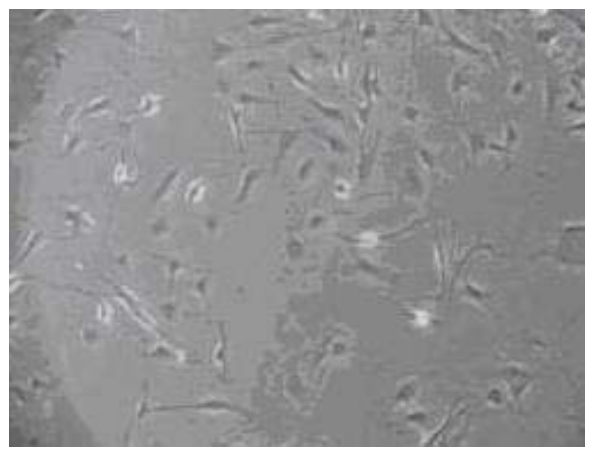

Figure 4. ICC exposure to $0.001 \%$ emodin for $15 \mathrm{~min}(\times 100)$. Ecphyma became shorten and cells slowly disconnected at $15 \mathrm{~min}$, and a significant reduction in cell number was observed.

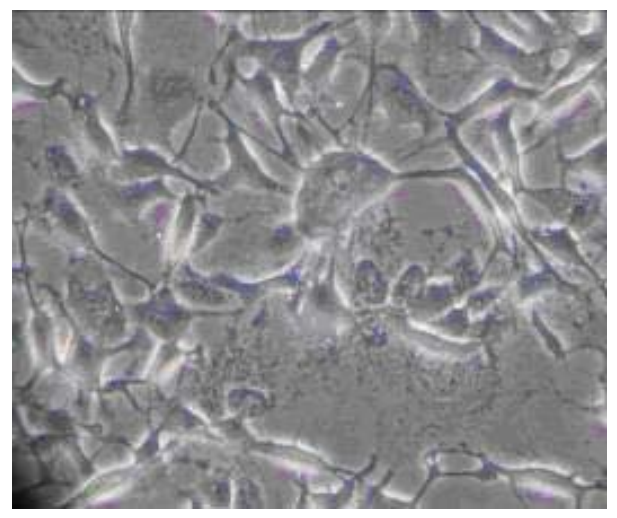

Figure 5. ICC exposure to $0.001 \%$ emodin for $60 \mathrm{~min}$ $(\times 100)$. The cell body became larger, the gap between the cell was increased which indicated the extent of cell damage became severer with time.

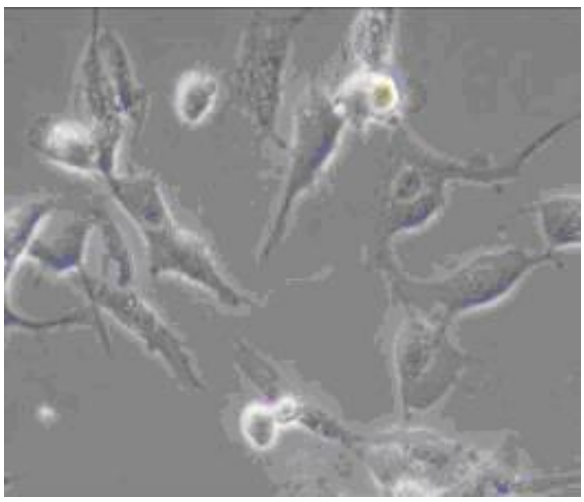

Figure 6. ICC exposure to $0.001 \%$ emodin for $180 \mathrm{~min}$ $(\times 100)$. The cell body became swell, cellular refraction disappeared, and the cell body disintegrated.

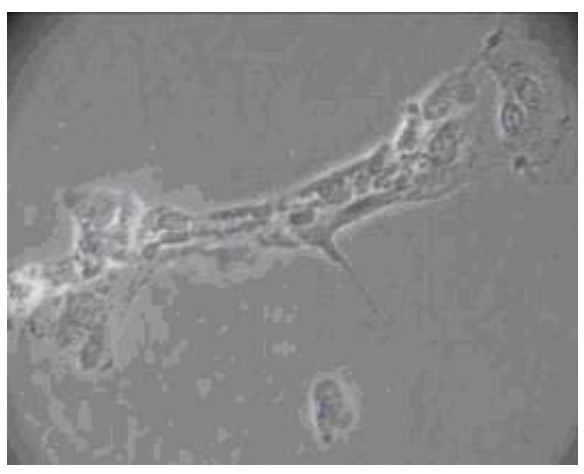

Figure 7. ICC exposure to $0.001 \%$ emodin for $360 \mathrm{~min}$ $(\times 100)$. No cell but debris can be observed.

Concentrations of electrolytes in colonic ICC were also changed after $0.001 \%$ emodin was administered. Since $30 \mathrm{~s}$ after administration, concentrations of $\mathrm{Na}^{+}$ and $\mathrm{Ca}^{2+}$ had been increased notably while $\mathrm{K}^{+}$had been decreased. Concentration of ATPase was influenced as well. $\mathrm{Na}^{+}-\mathrm{K}^{+}-\mathrm{ATP}$ and $\mathrm{Ca}^{2+}-\mathrm{ATP}$ concentrations had been declined significantly since $30 \mathrm{~s}$ (Tables 5 and 6).

Dysfunction of energy metabolism of colonic ICC 
Table 5. Effect on volume of $\mathrm{Na}^{+}, \mathrm{K}^{+}, \mathrm{Ca}^{2+}$ in ICC of $0.001 \%$ emodin $(\bar{X} \pm \mathrm{SD}, \mathbf{n}=\mathbf{8})$.

\begin{tabular}{ccccc}
\hline group & Time $(\min )$ & $\mathrm{Na}^{+}(\mathrm{mmol} / \mathrm{L})$ & $\mathrm{K}^{+}(\mathrm{mmol} / \mathrm{L})$ & $\mathrm{Ca}^{2+}(\mathrm{mmol} / \mathrm{L})$ \\
\hline control & 60 & $20.5450 \pm 0.2703$ & $79.5944 \pm 2.8097$ & $0.6046 \pm 0.0113$ \\
1 & 0.5 & $21.9265 \pm 0.1378^{\mathrm{b}}$ & $53.9354 \pm 3.4142^{\mathrm{b}}$ & $0.8930 \pm 0.0080^{\mathrm{b}}$ \\
2 & 1 & $23.7009 \pm 1.2260^{\mathrm{b}}$ & $47.4018 \pm 2.4520^{\mathrm{b}}$ & $0.9393 \pm 0.0041^{\mathrm{b}}$ \\
3 & 30 & $34.2902 \pm 2.8296^{\mathrm{b}}$ & $43.8530 \pm 0.2757^{\mathrm{b}}$ & $1.0186 \pm 0.0237^{\mathrm{b}}$ \\
4 & 60 & $39.7972 \pm 1.4048^{\mathrm{b}}$ & $41.0810 \pm 0.5405^{\mathrm{b}}$ & $1.1280 \pm 0.0071^{\mathrm{b}}$ \\
\hline
\end{tabular}

${ }^{\mathrm{a}} \mathrm{P}<0.05,{ }^{\mathrm{b}} \mathrm{P}<0.01$, vs control group, all below were the same.

Table 6. Effect on volume of $\mathrm{Na}^{+}-\mathrm{K}^{+}$-ATPase, $\mathrm{Ca}^{2+}$-ATPase in ICC of $0.001 \%$ emodin ( $\bar{X} \pm \mathrm{SD}, \mathbf{n}=\mathbf{8})$.

\begin{tabular}{cccc}
\hline group & $\mathrm{T}(\mathrm{min})$ & $\begin{array}{c}\mathrm{Na}^{+}-\mathrm{K}^{+} \text {-ATP } \\
(\mu \mathrm{molPi} / \mathrm{mgprot} / \text { hour })\end{array}$ & $\begin{array}{c}\mathrm{Ca}^{2+}-\mathrm{ATP} \\
(\mu \mathrm{molPi} / \mathrm{mgprot} / \mathrm{hour})\end{array}$ \\
\hline control & 60 & $34.2224 \pm 1.9644$ & $42.3098 \pm 3.9744$ \\
1 & 0.5 & $22.3085 \pm 1.4265^{\mathrm{b}}$ & $27.9788 \pm 3.2172^{\mathrm{b}}$ \\
2 & 1 & $14.2333 \pm 0.8266^{\mathrm{b}}$ & $14.1147 \pm 1.8304^{\mathrm{b}}$ \\
3 & 30 & $9.6540 \pm 0.6799^{\mathrm{b}}$ & $11.8857 \pm 1.7869^{\mathrm{b}}$ \\
4 & 60 & $5.8465 \pm 0.7199^{\mathrm{b}}$ & $8.0450 \pm 0.6129^{\mathrm{b}}$ \\
\hline
\end{tabular}

${ }^{\mathrm{a}} \mathrm{P}<0.05,{ }^{\mathrm{b}} \mathrm{P}<0.01$, vs control group , all below were the same.

showed after $0.001 \%$ emodin acted on cells. Since $30 \mathrm{~s}$ after action, concentration of glycogen had been decreased remarkably and lasted to $60 \mathrm{~min}$ (Table 7).

Concentrations of IP3 and cAMP in cytoplasm began to increase since $0.5 \mathrm{~min}$ after $0.001 \%$ emodin was added. Significant appeared at 30 min after emodin administration and lasted to $60 \mathrm{~min}$ (Table 8).

\section{Discussion}

ICC was the pacemaker and the motive factor of intestinal slow wave, which was one part of message transferring of intestinal nerve and the key of intestinal power maintenance. The transferring also depended on the network structure of ICC, which was the structural base of the whole intestinal electric activities. Neuron signal was transferred to smooth muscle via ICC [21-26].

The uniform design invented by Kai-tai Fang and Yuan Wang [27] had been widely used in pharmacology study. The correct result can be achieved by uniform design with smaller workload than orthogonal experimental design. Different concentrations of emodin $(0.001 \%, 0.005 \%, 0.01 \%, 0.05 \%, 0.1 \%, 0.5 \%, 1 \%)$ and time points $(0.5,10,30,60,120,240,360 \mathrm{~min})$ were generated respectively with the uniform statistical software to investigate the minimum toxicity concentration of emodin on the function of ICC in the study. Utility regression model were constructed by uniform design 3.0 software and grading-up of experiment condition was accomplished. Finally the minimum toxicity concentration of emodin on ICC were figured out as $0.001 \%$, and MTT assay showed the critical time points of toxicity
Table 7. Effect on glycogen in ICC of $0.001 \%$ emodin $(\bar{X} \pm$ $\mathrm{SD}, \mathrm{n}=8$ ).

\begin{tabular}{ccc}
\hline group & time $(\mathrm{min})$ & glycogen $(\mathrm{mg} / \mathrm{g})$ \\
\hline control & 60 & $0.3735 \pm 0.0062$ \\
1 & 0.5 & $0.1615 \pm 0.1766^{\mathrm{b}}$ \\
2 & 1 & $0.1479 \pm 0.0020^{\mathrm{b}}$ \\
3 & 30 & $0.1211 \pm 0.0022^{\mathrm{b}}$ \\
4 & 60 & $0.1085 \pm 0.0018^{\mathrm{b}}$ \\
\hline
\end{tabular}

${ }^{\mathrm{a}} \mathrm{P}<0.05,{ }^{\mathrm{b}} \mathrm{P}<0.01$, vs control group, all below were the same.

Table 8. Effect on volume of IP3, cAMP in ICC of $0.001 \%$ emodin $(\bar{X} \pm S D, n=8)$.

\begin{tabular}{cccc}
\hline group & time $(\min )$ & IP3 $(\mu \mathrm{g} / \mathrm{L})$ & cAMP $(\mathrm{nmol} / \mathrm{L})$ \\
\hline control & - & $60.6576 \pm 11.6097$ & $0.5000 \pm 0.1073$ \\
1 & 0.5 & $85.7534 \pm 12.9609$ & $0.5959 \pm 0.0571$ \\
2 & 1 & $89.5720 \pm 12.3400$ & $0.7039 \pm 0.1378$ \\
3 & 30 & $99.1546 \pm 11.4296^{\mathrm{b}}$ & $0.8317 \pm 0.0722^{\mathrm{b}}$ \\
4 & 60 & $105.1948 \pm 15.5747^{\mathrm{b}}$ & $0.9329 \pm 0.1580^{\mathrm{b}}$ \\
\hline
\end{tabular}

${ }^{\mathrm{a}} \mathrm{P}<0.05,{ }^{\mathrm{b}} \mathrm{P}<0.01$, vs control group, all below were the same.

were $0.5 \mathrm{~min}, 1 \mathrm{~min}, 30 \mathrm{~min}$, and $60 \mathrm{~min}$.

Malonaldehyde (MDA) was the end production of membrane lipid peroxidation triggered by oxyradical (originated from endocellular enzyme system or nonenzymatic system) [28]. Lactate dehydrogenase, as a mark enzyme of anaerobic metabolism, existed in cytoplasm. Acid phosphatase (ACP) was the typical enzyme of cytolysosome. When cytolysosome was broken, hydratase (typically ACP) was released to lyse macromolecule which resulted in cell degradation and the instability of cellular membrane. The increased extracellular concentrations of MDA, LDH and ACP can represent the enhanced membrane permeability and instability. In the study, the content of MDA and several defense enzymes activities were measured at the different times after treatments. The increased MDA had strong biotoxicity and caused impairment on membrane, which indicated that lipid peroxidation of cellular membrane was aggravated with the prolonged exposure to emodin. The enhanced extracelluar LDH and ACP validated the 
relationship between emodin reaction time and damage on membrane.

Cellular inner and outer membrane electrolytes balance was essential to maintain the $\mathrm{pH}$ value and osmotic pressure (OP). $\mathrm{Na}^{+}-\mathrm{K}^{+}$-ATPase and $\mathrm{Ca}^{2+}$-ATPase acted as the important transport enzyme to keep the concentration gradient in and out of cell. In the study, the content of cell membrane electrolyte leakage and several defense enzymes activities were also measured at the different times after treatments. After emodin acted on ICC, $\mathrm{Na}^{+}$ concentration was increased, and $\mathrm{K}^{+}$concentration was decreased. The concentration change may be caused by the damage of $\mathrm{K}^{+}$and $\mathrm{Na}^{+}$ion pump which inhibited the $\mathrm{Na}^{+}-\mathrm{K}^{+}$-ATPase' activity. And then the imbalance of $\mathrm{Na}^{+}$ and $\mathrm{K}^{+}$induced the OP change which resulted in the cell enlarge or even died.

The transferring between $\mathrm{Na}^{+}$and $\mathrm{Ca}^{2+}$ increased $\mathrm{Ca}^{2+}$ concentration. On the other hand, emodin lowered down the concentration of $\mathrm{Ca}^{2+}$-ATPase and diminished $\mathrm{Ca}^{2+}$ transferring through membrane which resulted in $\mathrm{Ca}^{2+}$ concentration rise. $\mathrm{Ca}^{2+}$ was also an important messenger of cell activity which played the key role in cell proliferation, differentiation and excretion [29]. Excessive $\mathrm{Ca}^{2+}$ caused free radical production, metabolic enzyme damage, membrane senescence and so on. The cellular $\mathrm{Ca}^{2+}$ concentration increase caused transglutaminase activation, which played a role in transferring glutamine to diaminocaproic acid. Therefore, stable exchanger protein emerged which induced the apoptotic body's formation. $\mathrm{Ca}^{2+}$ and calmodulin had ability to activate protease II that arrested cell cycle at $\mathrm{G}^{2}$ and led to cells' death.

Specific receptor-IP3 was the second messenger existed in smooth endoplasmic reticulum (SER) which stored $\mathrm{Ca}^{2+}$ in the cell. When IP3 was bonded with receptor of SER, $\mathrm{Ca}^{2+}$ passage was open and the stored $\mathrm{Ca}^{2+}$ outflow rapidly. It was proved that IP3 was increased before $\mathrm{Ca}^{2+}$ concentration increase [30,31]. The increase of cAMP as the second messenger could activate protien kinase-A, which led to phosphorylation of $\mathrm{Ca}^{2+}$ passage and $\mathrm{Ca}^{2+}$ rise in endochylema [32].

In the study, $0.001 \%$ emodin caused IP3 and cAMP rise after $30 \mathrm{~s}$, which differed from control group significantly and achieved peak value after $60 \mathrm{~min}$. The upgrading process of the two second messengers was roughly fit with the $\mathrm{Ca}^{2+}$ increase. IP3 was increased after emodin exposure, which led to IP3 bonding with receptor of SER and keep $\mathrm{Ca}^{2+}$ passage open. $\mathrm{Ca}^{2+}$ in endoplasmic reticulum outflow caused $\mathrm{Ca}^{2+}$ concentration in endochylema rise obviously. At the same time, cAMP content rose which indicated emodin bonded with recaptor to make adenyl cyclase active and cAMP increase. Furthermore, it also made PKA active and $\mathrm{Ca}^{2+}$ passage on membrane open, so $\mathrm{Ca}^{2+}$ outside could enter cell. It was reported that cAMP could inhibit cell division in vitro and promote differentiation. The result suggested that emodin could increase cAMP to slow down the cell growth and inhibit proliferation [33].

Glycogen in the cell was decreased significantly after emodin administration in a time relationship which showed that emodin caused cellular energy metabolism disorder. The result was in accordance with the conclusion reported that cAMP could induce glucogen synthesis phosphorylation via APK. It turned active glycogensynthesis-enzyme to non-active glycogen-synthesis-enzyme-D. By this way, it inhibited glycogen synthesis which was in accordance with glycogen reduction after emodin action.

Based on the investigation of minimum toxicity concentration of emodin on the function of ICC, the study showed that digestion system could be one of the targets of toxicity. Its mechanism could be predicted as lowing down $\mathrm{Ca}^{2+}$-ATPase and $\mathrm{Na}^{+}-\mathrm{K}^{+}$-ATPase or raising IP3 and cAMP which destroyed electrolyte balance. Damaging membrane and lysosomal caused hydratase released in the cell which made macromolecule and cell organelle broken down. Most of glycogen also broke down which induced energy metabolism disorder.

This article tested the toxicity of emodin to interstitial cells of Cajal (ICC) cultured in vitro, while the results would be different when emodin was oral intake and digested by the gastric juice and then moved to intestinal tract. And further experiment is carried out in our laboratory.

\section{Acknowledgements}

The study is supported by National Natural Science Foundation of China (No. 30230410); the National Basic Research Program of China (973 Program No. 2006CB504705, 2012CB723502); China Postdoctoral Science Foundation (No. 20100471662) and $\mathrm{PhD}$ Programs Foundation of Ministry of Education of China (No. 20105132120001).

The authors would like to express their thanks to Professor Xiaoyu Cao and Professor Xiushen Huang for technical support. Meanwhile, the authors are very grateful to Liyang Zhu, Tao Zheng, Xiaofang Xie, Yu Li and Xianna Gou for their help during the experiment.

\section{REFERENCES}

[1] C. L. He, L. Burgart, L. Wang, J. Pemberton, T. YoungFadok, J. Szurszewski and G. Farrugia, "Decreased Interstitial Cell of Cajal Volume in Patients with Slow-Transit Constipation," Gastroenterology, Vol. 118, No. 1, 2000, pp. 14-21. doi:10.1016/S0016-5085(00)70409-4

[2] L. Thomsen, T. L. Robinson, J. C. Lee, L. A. Farraway, M. J. Hughes, D. W. Andrews and J. D. Huizinga, "Interstitial Cells of Cajal Generate a Rhythmic Pacemaker Current," Nature Medicine, Vol. 4, No. 7, 1998, pp. 848- 
851. doi: $10.1038 / \mathrm{nm} 0798-848$

[3] J. C. Lee, L. Thuneberg, I. Berezin and J. D. Huizinga, "Generation of Slow Waves in Membrane Potential Is an Intrinsic Property of Interstitial Cells of Cajal," American Journal of Physiology, Vol. 277, No. 2, 1999, pp. 409423.

[4] S. D. Koh, T. W. Kim, J. Y. Jun, N. J. Glasgow, S. M. Ward and K. M. Sanders, "Regulation of Pacemaker Currents in Interstitial Cells of Cajal from Murine Small Intestine by Cyclic Nucleotides," The Journal of Physiology, Vol. 527, No. 1, 2000, pp. 149-162. doi:10.1111/j.1469-7793.2000.00149.x

[5] S. M. Ward, A. J. Burns, S. Torihashi and K. M. Sanders, "Mutation of the Proto-Oncogene c-Kit Blocks Development of Interstitial Cells and Electrical Rhythmicity in Murine Intestine," The Journal of Physiology, Vol. 480, No. 1, 1994, pp. 149-162. doi:10.1038/373347a0

[6] J. D. Huizinga, L. Thuneberg, M. Kluppel, J. Malysz, H. B. Mikkelsen and A. Bernstein, "W/Kit Gene Required for Interstitial Cells of Cajal and for Intestinal Pacemaker Activity," Nature, Vol. 373, No. 6512, 1995, pp. 347-349. doi: $10.1038 / 373347 \mathrm{a} 0$

[7] C. L. He, E. E. Soffer, C. D. Ferris, R. M. Walsh, J. H. Szurszewski and G. Farrugia, "Loss of Interstitial Cells of Cajal and Inhibitory Innervation in Insulin-Dependent Diabetes," Gastroenterology, Vol. 121, No. 2, 2001, pp. 427-434. doi:10.1053/gast.2001.26264

[8] K. Isozaki, S. Hirota, J. Miyagawa, M. Taniguchi, Y. Shinomura and Y. Matsuzawa, "Deficiency of c-Kit+ Cells in Patients with a Myopathic Form of Chronic Idiopathic Intestinal Pseudo-Obstruction," The American Journal of Gastroenterology, Vol. 92, No. 2, 1997, pp. 332334.

[9] S. E. Kenny, J. M. Vanderwinden, R. J. Rintala, M. G. Connell, D. A. Lloyd, J. J. Vanderhaegen and M. H. De Laet, "Delayed Maturation of the Interstitial Cells of Cajal: A New Diagnosis for Transient Neonatal Pseudoobstruction Report of Two Cases," Journal of Pediatric Surgery, Vol. 33, No. 1, 1998, pp. 94-98. doi:10.1016/S0022-3468(98)90370-0

[10] J. M. Vanderwinden, J. J. Rumessen, H. Liu, H. Liu, D. Descamps, M. H. De Laet and J. J. Vanderhaeghen, "Interstitial Cells of Cajal in Human Colon and in Hirschsprung's Disease," Gastroenterology, Vol. 111, No. 4, 1996, pp. 901-910. doi:10.1016/S0016-5085(96)70057-4

[11] S. Z. Yang, "The Divine Farmer's Materia Medica: A Translation of the Shen Nong Ben Cao Jing," Blue Poppy Press, Boulder, 1997.

[12] S. C. Li, "Ben Cao Gang Mu," People's Health Publishing Press, Beijing, 1982.

[13] Y. C. Kuo, H. C. Meng and W. J. Tsai, "Regulation of Cell Proliferation, Inflammatory Cytokine Production and Calcium Mobilization in Primary Human T Lymphocytes by Emodin from Polygonumhypoleucum Ohwi," Inflammation Research, Vol. 50, No. 2, 2001, pp. 73-82. doi:10.1007/s000110050727

[14] C. Musara and C. Vaillant, "Immunohistochemical Studies of the Enteric Nervous System and Interstitial Cells of Cajal in the Canine Stomach," Onderstepoort Journal of
Veterinary Research, Vol. 80, No. 1, 2013, pp. E1-E4.

[15] T. Suzuki, K. J. Won, K. Horiguchi, K. Kinoshita, M. Hori, S. Torihashi, E. Momotani, K. Itoh, K. Hirayama, S. M. Ward, K. M. Sanders and H. Ozaki, "Muscularis Inflammation and the Loss of Interstitial Cells of Cajal in Theendothelin ETB Receptor Null Rat," American Journal of Physiology-Gastrointestinal and Liver Physiology Vol. 287, No. 3, 2004, pp. 638-646. doi:10.1152/ajpgi.00077.2004

[16] T. Ordog, S. M. Ward and K. M. Sanders, "Interstitial Cells of Cajal Generate Electrical Slow Waves in the Murine Stomach," The Journal of Physiology, Vol. 518, No. 1, 1999, pp. 257-69.

doi:10.1111/j.1469-7793.1999.0257r.x

[17] P. Cheng, W. Lan, W. Yan-Hong, L. Yun-Xia and P. Yuan, "The Toxicity of Aconitine, Emodin on ICC Cell and the Anagonist Effect of the Compatibility," European Journal of Drug Metabolism and Pharmacokinetics, Vol. 34, No. 3-4, 2009, pp. 213-220. doi:10.1007/BF03191176

[18] J. J. Wu, T. P. Rothman and M. D. Gershon, "Development of the Interstitial Cell of Cajal Origin, Kit Dependence and Neuronal and Nonneuronal Sources Ofkit Ligand," Journal of Neuroscience Research, Vol. 59, No. 3, 2000, pp. 213-220.

[19] K. Ohshiro, A. Yamataka, H. Kobayashi, S Hirai, K. Miyahara, N. Sueyoshi, K. Suda and T. Miyano, "Idiopathicgastric Perforation in Neonates and Abnormal Distribution of Intestinal Pacemaker Cells," Journal of Pediatric Surgery, Vol. 35, No. 5, 2009, pp. 673-676. doi:10.1053/jpsu.2000.5940

[20] Y. Liu, D. A. Peterson and H. Kimura, "Schubert Mechanism of Cellular 3-(4,5-Dimethylthiazol-2-yl)-2,5-diphenyltetrazolium Bromide (MIT) Reduction," Journal of Neurochemistry, Vol. 69, No. 2, 1997, pp. 581-593. doi:10.1046/j.1471-4159.1997.69020581.x

[21] S. D. Koh, K. M. Sanders and S. M. Ward, "Spontanrous Electrical Rhythmicity in Cultured Interstitial Cells of Cajal from the Murine Small Intestine," The Journal of Physiology, Vol. 513, No. 1, 1998, pp. 673-676. doi:10.1111/j.1469-7793.1998.203by.x

[22] J. D. Huizinga, T. L. Robinson and L. Thomsen, "The Search for the Origin of Rhythmicity in Intestinal Contraction from Tissue to Single Cells," Neurogastroenterology \& Motility, Vol. 12, No. 1, 2000, pp. 673-676. doi:10.1046/j.1365-2982.2000.00177.x

[23] T. K. Smith, J. B. Reed and K. M. Sanders, "Origin and Propagation of Electrical Slow Waves in Circular Muscle of the Canine Proximal Colon," American Journal of Physiology, Vol. 252, No. 2, 1987, pp. 215-224.

[24] I. Berezin, J. D. Huizinga and E. E. Daniel, "Structural Characterization of Interstitial Cells of Cajal in Myenteric Plexusand Muscle Layers of Canine Colon," Canadian Journal of Physiology and Pharmacology, Vol. 68, No. 11, 1990, pp. 1419-1425. doi:10.1139/y90-216

[25] E. E. Daniel, Y. Sakai, J. E. Fox and V. Posey-Daniel, "Structural Bases for Function of Circular Muscle of Canine Corpus," Canadian Journal of Physiology and Pharmacology, Vol. 62, No. 10, 1984, pp. 1304-1314. doi: $10.1139 / \mathrm{y} 84-219$ 
[26] S. M. Nicholson and R. Bruzzone, "Gap Junctions: Getting the Message through," Current Biology, Vol. 7, No. 6, 1997, pp. R340-R344. doi:10.1016/S0960-9822(06)00169-2

[27] P. Wang, Y. Z. Wang and J. M. Shen, "Uniform Design and Its Application in Pharmacy," Vol. 6, No. 4, 1989, p. 297.

[28] C. J. Li, Q. M. Zhang, M. Z. Li, J. Y. Zhang, P. Yu and D. M. Yu, "Attenuation of Myocardial Apoptosis by AlphaLipoic Acid through Suppression of Mitochondrial Oxidative Stress to Reduce Diabetic Cardiomyopathy," Chinese Medical Journal, Vol. 122, No. 21, 2009, pp. 673676.

[29] P. L. Zhang, "Research Progress of Quercetin's Effects on Cell Proliferation," Journal of Luzhou Medical College, Vol. 22, No. 2, 1999, pp. 168-170.

\section{Abbreviations}

ACP: Acid phosphatase;

ATP: Adenosine triphosphate;

CAMP: Cyclic adenosine monophosphate;

DMSO: Dimethyl sulfoxide;

HCL: Hydrochloric acid;

ICC: Interstitial cells of Cajal;

IP3: Inositol-1,4,5-triphosphate;
[30] M. J. Berridge, "Inositol Trisphosphate and Calcium Signaling Mechanisms," Biochimica et Biophysica Acta, Vol. 1793, No. 6, 2009, pp. 933-940. doi:10.1016/j.bbamcr.2008.10.005

[31] K. Mikoshiba, "IP3 Receptor/Ca ${ }^{2+}$ Channel: From Discovery to New Signaling Concepts," Journal of Neurochemistry, Vol. 102, No. 5, 2007, pp. 1426-1446. doi:10.1111/j.1471-4159.2007.04825.x

[32] W. L. Huang and X. F. Zhu, "Signal Transduction," People's Health Publishing House, Beijing, 2005.

[33] Z. Y. Han, J. X. Cheng and J. S. Liu, "Effect of Parathyroid Hormone (1-34) on cAMP, IP3, $\mathrm{Ca}^{2+}$ Production in SaOS-2," Chinese Pharmacological Bulletin, Vol. 14, No. 4, 1998, pp. 326-328.

M199: M199-culture medium;

MTT: Thiazolyl blue;

MDA: Malondaldehyde;

NAOH: Sodium hydroxide;

OD: Optical density;

PBS: Phosphate buffered saline;

Rpm: Revolution Per minute;

SCF: Stem cell factor 